\title{
Disparate geographies of labour: The Philippines in times of globalisation
}

\author{
Anne Clausen, London
}

\section{Introduction}

Within the context of globalisation, labour market issues are crucial to social and spatial tensions marking current transformations in less and more developed countries. Analysis of labour market issues also allows insight into the myriad ways in which people respond to political and economic crises, to poverty and inequality. In the case of the Philippines, the generation of labour has been called the central obstacle to a high(er) (e)quality of life (HANISCH 2000). Therefore, the generation and maintenance of high rates of employment are principal objectives of state governmental policies (National Economic and DevelopMENT Authority (NEDA) 2001).

This paper seeks to discuss relations and interactions of the Philippine labour market with regionally disparate development and the course of (economic) state policies. Economic globalisation provides the framework to this labour-disparity-policy nexus. The paper provides an overview of the current state of labour in the Philippines embedded within an historical context and contributes towards the analysis of its structural and policy challenges.

Since the mid-1980s, economic globalisation has on the one hand, been understood to comprise an ever increasing networking with regards to expanding international division of labour, increasing foreign direct investment (FDI) and world trade, and the global integration of capital markets. Social and economic contexts are detached from their traditional local settings. Competition increasingly takes place at national and global, regional and local levels. Economic globalisation is said to trigger off relocation of production to cheaper, yet often less developed production sites (like the Philippines), creation of employment and transfer of technologies, hence contributing towards a general increase in income and knowledge. Within this context, national markets aim to enlarge their export-oriented sectors to participate in global trade. Employment and education structures are adapted to global market requirements and increasingly, people from less developed countries take advantage of these global facilities through migration. International labour migration is claimed to release unemployment pressures and even to provide developmental incentives to the place of origin through transfer of remittances. From this perspective, globalisation represents a catalyst for poorer people and regions to catch up with development, to combat poverty and inequalities (BürRLIN 2000).

On the other hand, globalisation is also claimed to operate sectorally selective on the side of services and industries and to the detriment of agriculture. Globalisation is criticised for neglecting the rights and needs of workers, in particular of rural peasants and the landless, and to further push their socio-economic marginalisation. Those who are integrated in the global economy, such as migrant and female workers, are disproportionately exposed to the volatility of global (labour) markets, and to exploitation in terms of wages and working conditions at low social standards. In labour-intensive industries, the labourers do not benefit from knowledge transfer because the investors explicitly require less educated, cheap and less rights-conscious workers. Hence, from this perspective, globalisation contributes towards the exclusion of agricultural labourers and the exploitation and increasing vulnerability of workers in service and industry (RIGG 2003).

Spatially, globalisation would appear to operate selectively in favour of large, mostly urban(ised) regions like Metropolitan Manila. They are the preferred sites of industry and services as they offer both the required resources and global connections. In contrast, remote and rural regions are generally neglected by globalisation. Although these so-called peripheries are more prominent in rural areas, they also exist in central urban places.

In view of the above-described effects of globalisation, the classic governmental function of providing social protection to vulnerable groups and promoting social (e)quality becomes increasingly complex. Governments face the competition of global, regional, local, state and non-state actors in daily policy making and implementation. Emerging societal discontent may threaten inner cohesion and the authority of the government. Against this background, this article follows a policy-oriented analysis of the Philippine government's attempt at fostering their country's position in a globalising economy while simultaneously reducing socio-economic regional disparities.

It is emphasised here that globalisation is only one of many historical periods that shape labour markets. Further, disparate development is both a process and a state that is constantly being redefined. For this reason, the article refers to historical aspects where necessary to explain labour patterns, trends and disparity in the Philippines. 


\section{Methodology}

The article draws on quantitative secondary data, qualitative expert interviews, field observations and academic literature for its analysis. The analysis itself is embedded within a larger research project titled «Socio-economic regional disparities and globalisation in Southeast Asia» and managed by the Department of Geography, University of Cologne, Germany. Use was made of a Geographical Information System to visualise globalisation and disparity production in the Philippines. For this purpose, statistical data from 29 official sources were thematically selected, compiled and processed. The data was adjusted to the changing administrative classifications of provinces and regions. Figure 1 displays the administrative classification in use from 1998 to 2001 which is the main period of reference targeted in this article.

\section{Overview of the labour market, labour policies and labour crises in the Philippine political economy}

\subsection{Unemployment and underemployment}

Unemployment and underemployment are seen as central to Philippine socio-economic problems and in direct relation to the production of disparities and poverty (National ECONOMIC AND Development AuthoRITY (NEDA) 2001). Underemployment is defined as including all employed persons who express the desire to have additional hours of work in their present job or an additional or new job with longer working hours. Although the Philippine labour force participation rate in 2001 was with $67.5 \%$ the highest in ten years, in comparison to other Southeast Asian countries this figure remains low (National Statistical CoorDINATION BOARD (NSCB) 2002b). Figure 2 shows the annual national employment and underemployment rates between 1991 and 2001, and employment rates by region in 2001. Officially, employment rates range between $89.9 \%$ and $92.6 \%$. Unemployment rates thus fluctuate around $10 \%$.

Informal labour, although not included in these statistics, is considered to make an important contribution to the labour market. Quantitative data on the informal sector is vague. SCHNEIDER (1999) defined $16 \%$ to $34 \%$ of all urban employment in the cities of Baguio and Zamboanga as informal («informal» being understood as referring to self-employed persons without official licence and enterprises with less than five employees). Neither a formal unemployment income support scheme nor an official social security net exists in the Philippines. There is thus little incentive for people without work to register themselves as unemployed. As a consequence, unemployment totals may be assumed to be many times higher than offi- cial records. For this reason, available data needs to be treated with caution. Nevertheless, the data does allow for description of tendencies which can be utilised as qualitative indicators of patterns and trends.

Employment rates, despite significant fluctuation, increased on the whole during the early 1990's before dropping dramatically after 1996 . The situation did not seem to improve noticeably until 2001. Underemployment, like the unemployment rates, follows an opposite trend, yet with estimates between $23.7 \%$ (1998) and $16.6 \%$, it is considerably higher than the unemployment rates. The labour underutilisation rate peaked in 1998 with $33.3 \%$. These trends correspond to the boom and bust cycle of the Philippine gross domestic product (GDP). During the period of analysis, the country suffered from three socio-economic crises: in 1983/84, in the early 1990s and in 1997/98. Especially the «Asian Crisis» of $1997 / 98$ made the dependency of the Philippine labour market on the volatile global market apparent. Recessions in the agricultural sector and in rural regions were, however, despite opposing media reports, more likely triggered by the natural phenomenon of El Niño and the following drought.

\subsection{Regional disparities in the Philippine labour market}

Figure 3 presents absolute employment according to sector and province in 2001. In terms of size, the differences in employment may be attributed to the uneven distribution of population. This distribution in turn, stems predominantly from enduring migration fluxes towards the attractive economic centres of the country (no official statistics are available). In absolute numbers, employment chances are highest in the National Capital Region (NCR, also referred to as Metropolitan Manila) and surrounding regions, to a lesser extent in Cebu and Negros Occidental in the Visayas, and in and around Davao del Sur in Mindanao. According to Fig. 2 , it would seem that the unemployment rate in 2001 was also highest in the NCR, followed by Southern Tagalog, Central Luzon and Central Visayas. In contrast, the Autonomous Region of Muslim Mindanao (ARMM), despite low absolute employment, also boasts the lowest unemployment rate in the country.

These findings may be directly linked to the interplay between the city system and globalisation in the Philippines (Fig. 1). The NCR clearly dominates the city system with 9,033,183 inhabitants, followed by Davao City in Davao del Sur, and Cebu City/Metro CebuMandaue in the Cebu province. In the provinces of Central Luzon and the Eastern parts of Southern Tagalog, the concentration of cities is exceptionally high. It thus seems obvious that highest absolute employment as well as relative high unemployment rates are 


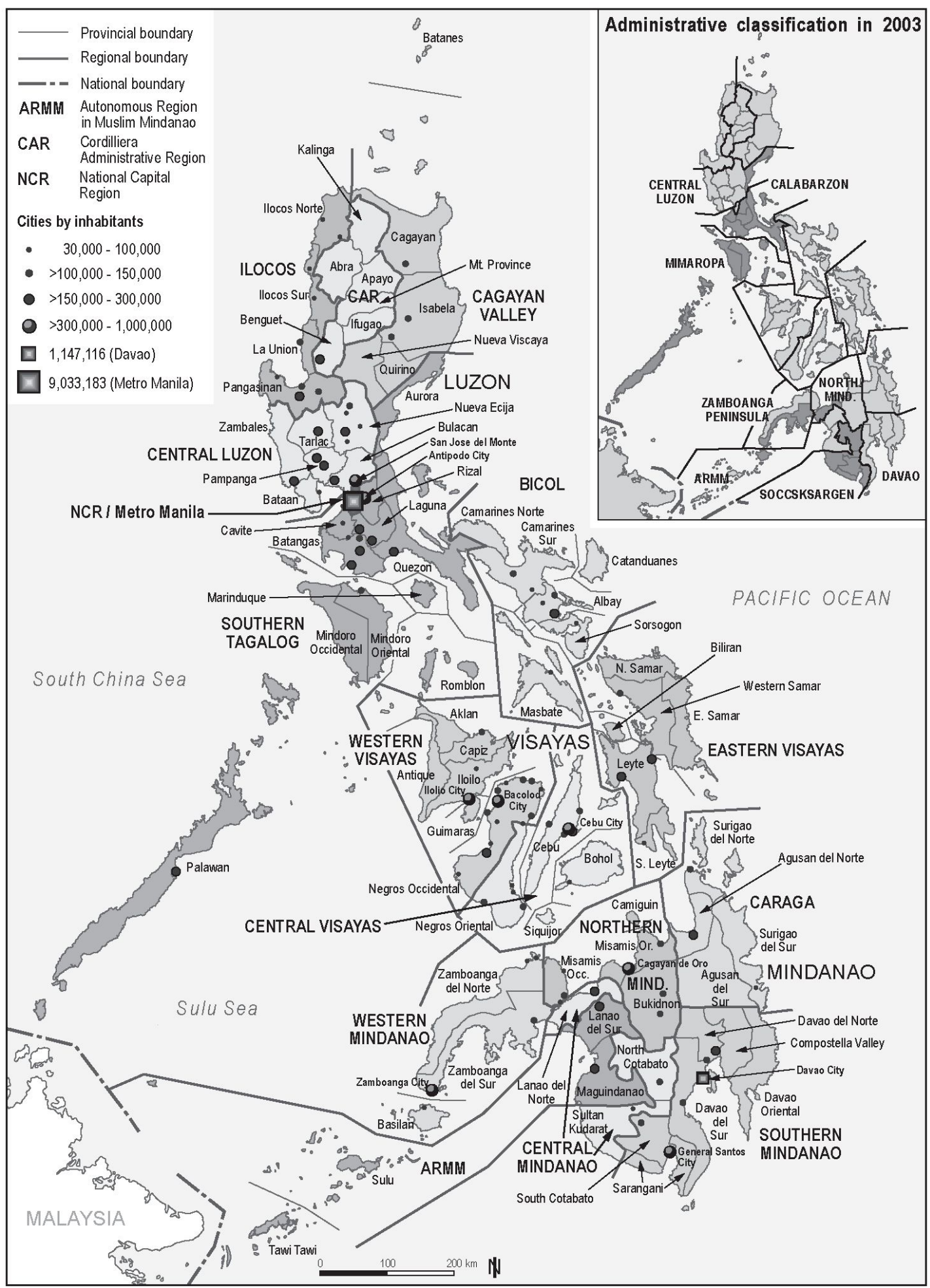

Fig. 1: Administrative classification of regions and provinces in the Philippines (period between 1998-2001) and cities by inhabitants (2003)

Regionale und provinzielle administrative Gliederung der Philippinen (1998-2001) und Städtesystem nach Einwohnern (2003)

Classification administrative des régions et provinces des Philippines (1998-2001) et population des villes (2003) Draft and lay-out: A. Clausen; cartography: U. BeHa; sources: Atlas of the Philippines 1998; map of the Philippines 1:250 000, 1976; UNEP/GRID 1995; National Statistical Coordination Board (NSCB) 2002a, 2003a 


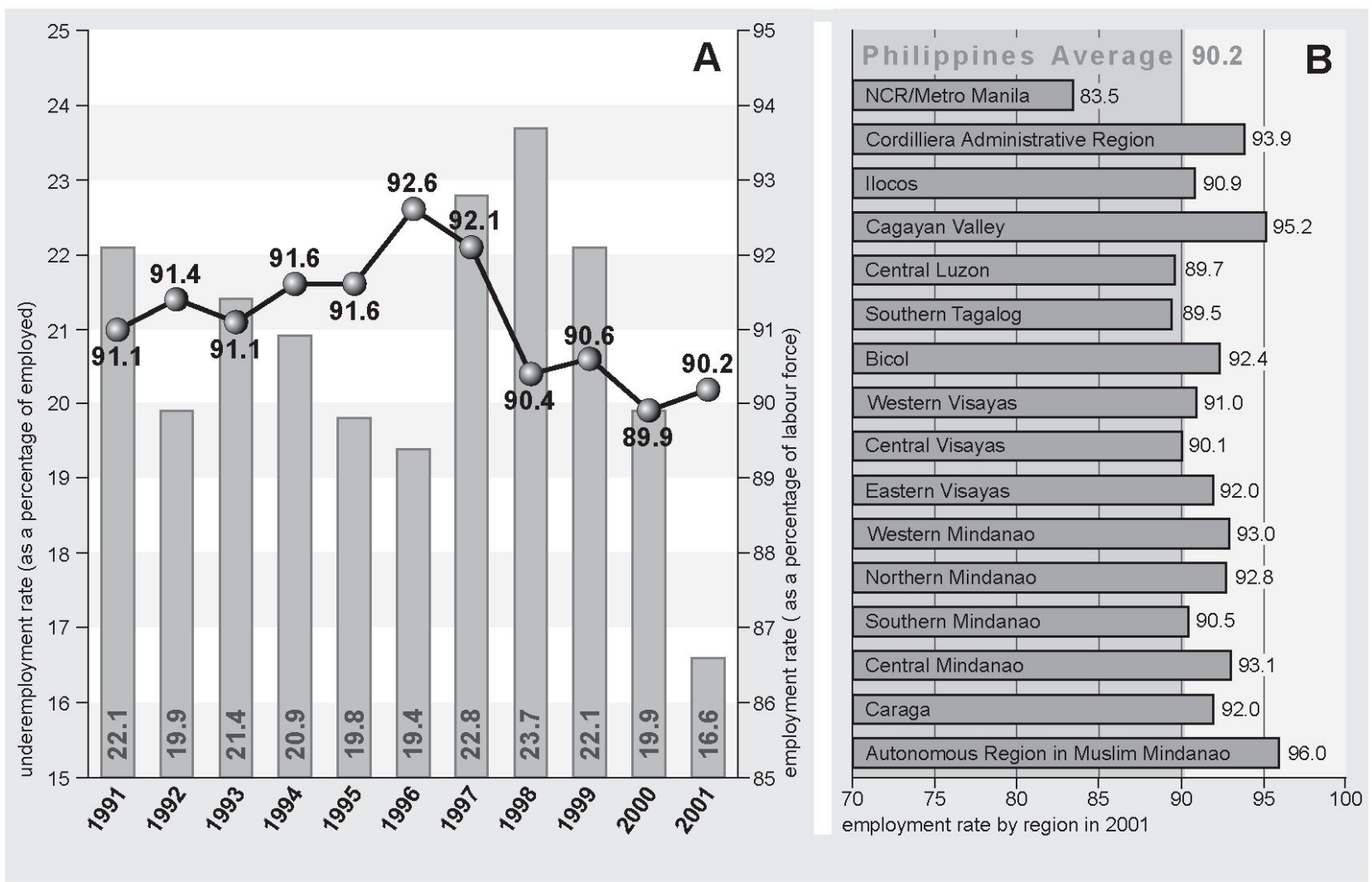

Fig. 2: Comparison of employment and underemployment rates in households with members over the age of 15 (1991-2001) and employment rate by region (2001)

Beschäftigung und Unterbeschäftigung der Haushaltsbevölkerung über 15 Jahre von 1991-2001 und regionale Beschäftigungsraten 2001

Taux d'emploi et de chômage de la population de plus de 15 ans de 1991 à 2001 et taux d'emploi par région en 2001

Draft: A. Clausen; graphics: U. Beha; Source: National Statistical Coordination Board (NSCB) 2002b

to be found in the largely urbanised regions of the Philippines. In contrast, the Cordillera Administrative Region (CAR), Cagayan Valley, Eastern Visayas and the ARMM, selected provinces of Northern and Central Mindanao and Caraga as well as Western provinces of Southern Tagalog have lower absolute employment rates and relatively low unemployment rates. According to Figure 1, these regions also have a stronger rural character in common.

Several explanations for these patterns exist: Firstly, cities, and foremost Metro Manila, are the major «marketplaces» of globalisation in the Philippines and hence, sites of employment generation. Simultaneously, cities disproportionately face the volatility of globalisation and high rates of job turnover. For example, the crisis of $1997 / 98$ was mainly felt in Metro Manila, with $58.13 \%$ of all establishment closures between 1998 and 2000 being recorded here (SCIENCE AND TeChNOLOGY
Education Network (Stednet) 2002). Secondly, the economy in those regions with little unemployment, like the ARMM, is based above all on (subsistence) agriculture and fisheries, both sectors with many family workers and little (registered) dismissals. Thirdly, reference to historical development allows insight into the urban focus of the current political economy. Due to the past need for sea trade centres, many cities in the Philippines were founded at the coast (see Fig. 1). Until today, these cities remain better accessible for trade and investors and function as entry points into the mainland. The dominance of Metro Manila and its surrounding provinces owes allegiance to Spanish and American colonial activities, as well as to centralisation of state power organisation and resources by subsequent Filipino governments. This centralisation consequently pulled more and more economic actors (and migrants) to the cities (Gonzales et al. 2003). Finally, public policy appears until the 1990's to have targeted 


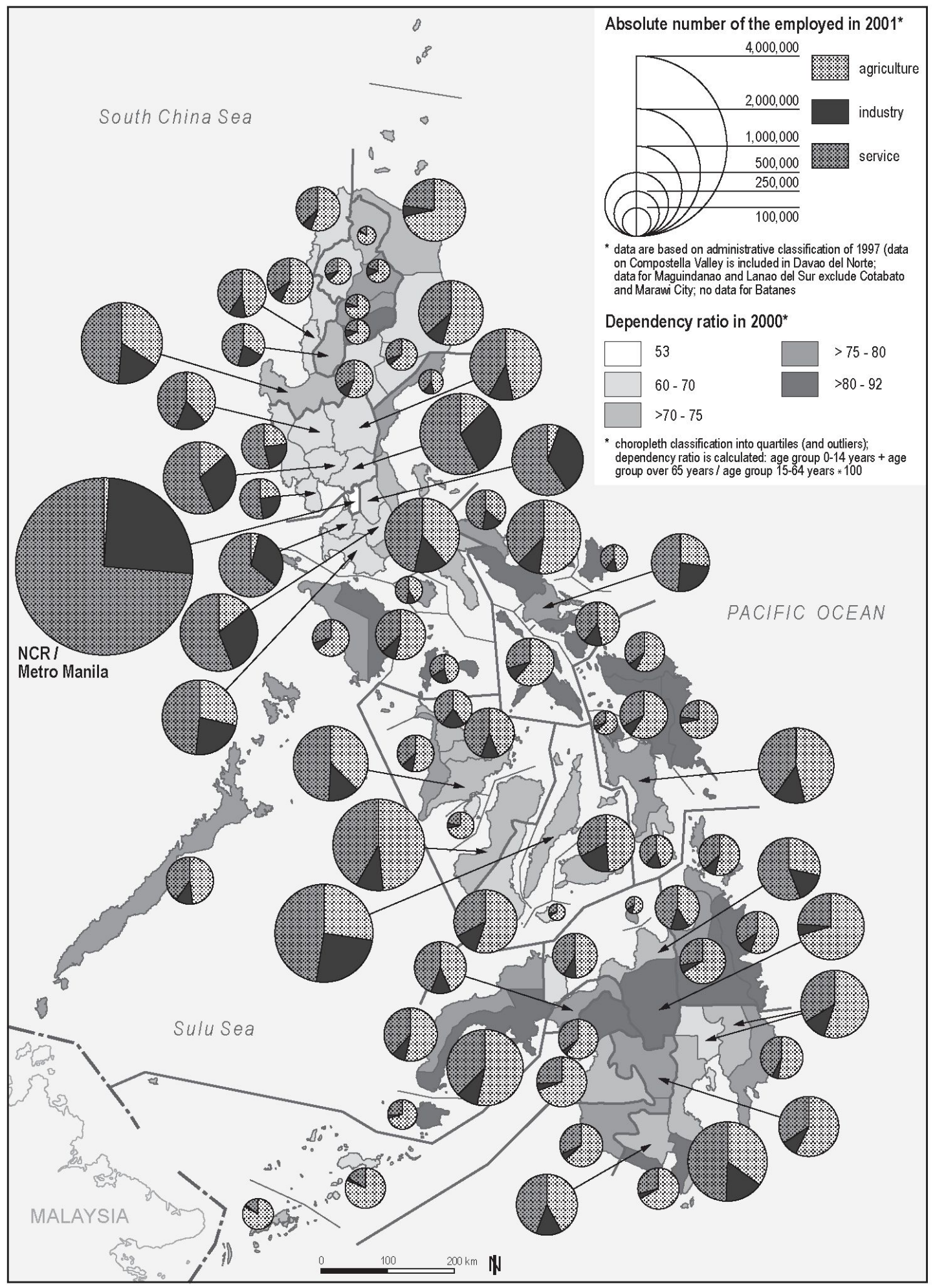

Fig. 3: Absolute sectoral employment by province in 2001 and provincial dependency ratio in 2000 Absolute Beschäftigung nach Sektoren und Provinzen (2001) und altersbedingter Abhängigkeitsindex nach Provinzen (2000)

Emploi sectoriel total par province en 2001 et ratio de dépendance par province en 2000

Draft and lay-out: A. Clausen; cartography; U. Beha; Sources: National Statistical Coordination Board (NSCB) 2001; National Statistical Office (NSO) 2001/2002 
urban agglomerations as major growth and labour poles for their respective hinterlands (MANASAN \& MerCado 1999).

Figure 3 presents an overview of sectoral labour division in the individual provinces in 2001. Manila and its proximate provinces are primarily characterised by employment in tertiary and secondary sectors. The same may be said for Cebu province, Iloilo, Davao del Sur and Misamis Oriental. Agriculture remains the dominant sector of employment in most of residual Mindanao, the Eastern Visayas, Northern Luzon, as well as the Western parts of Southern Tagalog.

The above analysis indicates that the regional distribution of absolute employment, sectoral employment and the city system are interrelated phenomena, and suggests a categorisation of the Philippines into «centre» and «peripheral» regions. Urban or urbanised regions generally show higher absolute employment, particularly in the industrial and services sectors. Thus, the NCR, Central Luzon, the Eastern provinces of Southern Tagalog, and the provinces of Cebu and Davao del Sur may be categorised as such centres. In contrast, many rural and remote regions where agriculture and lower absolute employment prevail could be allocated to the category of periphery. Examples of such regions would include residual Mindanao, Bicol, Eastern Visayas, major parts of Northern Luzon and the Western provinces of Southern Tagalog (Pernia \& Quising 2002). It should be mentioned that at local scales, peripheries also exist within the centre regions and vice versa. For example, poverty is an issue in urban areas and some remote islands are major high-class tourist destinations.

\subsection{Sectoral labour: The agricultural (policy) dilemma}

Policy interventions have affected the above described spatial economy to a large extent. Under President MARCos agriculture was technically and financially promoted, while industries and services were strongly controlled and regulated (Manasan \& Mercado 1999). Since 1985, economic reforms have aimed at the expansion and globalisation of services and industries. In 1985, agriculture accounted for $26.7 \%$ of the economy, industry for $33 \%$ and services for $40.4 \%$; by 2003 , the share of the primary sector had dropped to $19.9 \%$, the secondary sector stagnated at $33.5 \%$, and the tertiary sector had increased to $46.7 \%$.

Even so, in 2001,37.7\% of all employed Filipinos were officially engaged in agriculture, $46 \%$ in services and $16.3 \%$ in industry. These figures include neither unpaid family workers, people pursuing several jobs at a time, nor the informal sector. Therefore, it may be assumed that particularly within the agricultural sector, labour totals are likely to be higher, some experts estimating as much as 64\% (SHAw 1999). However, with globali- sation focussing on urban «marketplaces» of services and industries it seems the Philippine government is failing to provide the agricultural sector and thus the rural regions with effective policy interventions.

A striking policy measure is the establishment of Special Economic Zones (SEZ) which aims at using global enterprise networks as levers for local development in urban and rural areas. In practice, however, it seems that existing spatial and economic divides tend to be replicated. Further, most of the SEZ appear to be badly integrated into local subcontractor systems and import between $40 \%$ to $75 \%$ of their production costs (Hanisch 2000). In 2003, Southern Tagalog clearly outnumbered all other regions with $71 \mathrm{SEZ}$, followed by the NCR with 24, Central Luzon with 15 , and Central Visayas with 13. Again, the Mindanao, Eastern and Western Visayas, and Northern Luzon Regions faired less well with 41 SEZ between them (PhILIPPINe EcoNomic Zone Authority (PEZA) 2003).

Similarly, in 1998, the Agriculture and Fisheries Modernisation Act promised to mitigate limitations in the agricultural sector by way of global market orientation. However, Philippine policy frameworks appear to not always be transferred from national to local levels. For example, a planning office in the Central Visayas responsible for setting up provincial policies on agriculture was not aware of the existence of the Agriculture and Fisheries Modernisation Act at all (information derived during field visits).

It ought to be noted that the situation of agricultural development in the Philippines is additionally impeded by natural phenomenon, like El Niño, and natural disasters, like unusually heavy typhoons, frequent flooding, landslides and volcanic activities.

As a result, poverty in many regions overtly reliant on agricultural production is on the increase. In the year 2000, 26.5 million or 34\% of Filipinos lived below the poverty threshold. While urban poverty has stagnated at $15 \%$ since 1997 , rural poverty has risen from $39.9 \%$ to $41.4 \%$ (National Statistical CoOrdination Board (NSCB) 2003b).

\section{Problematic dimensions of population: Alternative views on labour}

\subsection{Population growth}

Rapid population growth is another significant pressure factor on the present and future Philippine labour markets. The Philippine population has almost multiplied by four since 1948 and totalled 81,408,000 inhabitants in mid-2004. The population growth rate peaked at $3.1 \%$ in 1970 and reduced to a - still high $-2.4 \%$ 
in 2000 (National Statistical Coordination Board (NSCB) 2002b). As a result, the national age dependency ratio in 2000 was an unfavourable 69.8. This means that during that year, $59 \%$ of the Philippine population was between 15 and 45 years old. These $59 \%$ cared for themselves and another $37 \%$ young and $4 \%$ elderly (National Statistical Office (NSO) 2001/2002). Given that more than one third of the population is below fifteen, the population entering the labour force will continue to grow rapidly for at least the next fifteen years. Policies to reduce population growth are therefore indispensable.

The main reasons for the rapid increase in population lie again with national policies: Firstly, since the 1980 's, the Philippine government has only given modest political support to population programmes. This course of policy has to be seen in the context of the systematic resistance against population management by the influential Catholic Church (about 94\% of Filipinos are Christians). Under President Marcos, the Philippines in 1970 were among the first in Southeast Asia to launch an official family planning programme. The subsequent governments did not follow up this programme. Currently, under President ARroyo the focus is on responsible parenthood and informed choice rather than artificial birth control. Ironically today, the neighbouring countries that once took the Philippines as policy model have by and large overtaken the country in terms of successful population management (ORBETA \& PERNIA 1999).

The provincial age dependency ratios in Fig. 3 illustrate the identified disparities in the labour market from the perspective of the population: The peripheries have high dependency ratios, and as a consequence lower percentages of 15 to 64 year olds, despite having the highest total fertility rates in the country. The majority of the 15 to 64 year olds have migrated to the urbanised centres which, in turn, have lower dependency ratios, headed by the NCR. It follows that the peripheries are losing their most productive population segment and their human capital base - both of which are essential factors for fostering substantial change in their political economy landscape.

\subsection{The Philippine migrant nation}

It is not only the peripheries that are losing their prime labour segment. The brain drain from the entire country is substantial. Since 1974, the Philippine national government has sought to present the populationemployment dilemma as a benefit in the sense that a large pool of abundant workers were available to be educated for export to global labour markets. As mentioned above, a cheap and low educated labour force is the major production factor used to motivate foreign investors to settle in the Philippines. In addition, professional skills development, especially in the information technology health sectors, aims at attracting higher-valued production activities to the country. Particularly professionals migrate to meet labour shortages in neighbouring Asian countries, the USA and Europe. Looking at the national government expenditure of 2002, the Education, Manpower Development and Culture Programme received with $16.6 \%$ or 129.672 million Pesos the highest share of government expenditure programmes. On the other hand, the Employment, Welfare and Social Security Programme obtained only a fraction of available resources (3.9\% or 30.36 million Pesos) (National STatistical CoORdiNATION BOARD (NSCB) 2002b).

Indeed, the Philippines have become the largest migrant nation in the world with an official public-private overseas employment infrastructure and several official recruitment agreements with foreign countries (Tyner 1999). Migrants' remittances are seen as essential incentives for development at home and President ARroyo has called migrant workers «overseas investors». In 2001, the stock estimate of overseas Filipino workers (i.e. under contract) totalled 7,402,894 - around $9 \%$ of the total population and $20.2 \%$ of the labour force. In addition, between 1981 and 2001, 657,097 unemployed Filipinos emigrated permanently $24.24 \%$ of which were students who intended to benefit from «global» education (Commission on FILIPINos Overseas (CFO) 2002). Officially, migrants sent back $6,031,271,000$ US $\$$ of remittances in 2001 alone.

However, migration requires a minimum amount of existing financial and network resources. It is not an option for the (very) poor, that is for the majority of the inhabitants in the economic peripheries. The largest number of labour migrants comes from the urbanised, globalised core regions around Manila where most of the training apparatus and $99 \%$ of labour recruiters are situated. Ilocos province, for example, registers large numbers of out-migrants being a traditional source area for migrants. On the other hand, current trends of female labour migration to meet global demands for nurses and housemaids draw mostly on population groups in the peripheries, as especially housemaids do not require a specific education. Attempts to turn these migrants from nurses and housemaids into entrepreneurs who provide development incentives, however, so far remain small-scaled and often inadequately focussed.

\section{On socio-cultural and political conflicts and inequalities: Additional impediments to regional development in the periphery}

Besides globalisation and economic and population policy, conflicts arising out of socio-cultural diversity and historically grown unequal power relations have 
worked to the detriment of developmental policies, especially in the peripheries.

Firstly, the Philippines are in socio-cultural terms an extremely diverse country with more than 51 major ethno-linguistic groups. On the grounds of this sociocultural and ethno-linguistic background, several conflicts have developed and persisted for many decades, especially the armed conflicts between the state government and various Moro groups (the politically correct formulation of the previously used religious term Muslim), and the communist guerrilla organisation of the National People's Army (NPA). Both groups, Moro and NPA, basically justify their resistance with political agendas for more equitable socio-economic reforms, land entitlements, and more political autonomy. These political tensions and insurgencies take place especially in the peripheries, and have inter alia hampered the progress of development projects (SHAw 1999).

Secondly, spatial inequalities in the rural periphery have historical roots in long-established forms of social and political organisation and power relations that still persist. Local clientilistic patronage leadership is facilitated through the geographical fragmentation of the Philippines into 7107 islands. The local leadership is responsible for the highly uneven distribution of land ownership in the rural Philippines and inherent vulnerability of the landless and peasant workers with regards to structural and policy deficits. The implementation of the Comprehensive Agrarian Reform Program (CARP) launched in 1988 to specifically solve such socio-political inequalities by means of land redistribution proves to be slow and difficult due to the resistance of landowners, who are often at the same time politicians, the multiplicity of institutions involved, and the lack of monitoring and evaluation.

Thirdly, attempts to increasingly decentralise the administrative and political economy of the country face difficulties. In 1991, the government increased official authority for the regions with the so-called Local Government Code, which made available resources and personnel to local governments. However, the code was only partially successful due to continuously weak local governments, re-centralisation tendencies, personalised politics, corruption and cronyism in the peripheral regions (GEorge 1998). In fact, decentralisation in the Philippines seems to deal less with substantive debates over development strategies than with short-term political calculations.

During the last few years, some local governments have started to cooperate with actors of the civil society, that is non-governmental or people's organisations and the private sector, in order to compensate some of their deficiencies and to effectively reach out to the needy. For example, in Bohol province, an integrative poverty reduction strategy is being successfully applied to create employment, combat poverty and reduce inequalities in the peripheries of the province.

\section{Conclusion}

To conclude, alongside globalisation processes, state policies have turned to support the service and industry sectors despite the fact that the majority of Filipinos still engages in agriculture. Moreover, the urban «marketplaces of globalisation» and already better-developed centres of NCR, Central Luzon, the Eastern provinces of Southern Tagalog, and the provinces of Cebu and Davao del Sur have profited more from economic state policies since colonial times. In contrast, the agricultural sector, and thus most of the rural regions, was neglected in terms of effective policy interventions. Consequently, rural regions and their inhabitants, characterised by an over-proportionate reliance on agricultural production, have become economic peripheries. Residual Mindanao, Bicol, Eastern Visayas, major parts of Northern Luzon and the Western provinces of Southern Tagalog are such peripheries. At the same time, the (rural) Philippines experience one of the highest population growth rates in the Southeast Asian region. Due to the lack of labour perspectives the majority of 15 to 64 year olds currently migrate from the peripheries to urban centres. Caught in a vicious cycle, these peripheries and their inhabitants are cumulatively driven into deeper poverty. The government has tried to enhance the targeting of development in the peripheries through decentralisation. However, this has proven difficult in the face of enduring tendencies towards re-centralisation, corruption and personalised politics in local governments, long-established unequal power relations and landownership. In addition, the continuing armed conflicts between the state government and the NPA and Moro groups, respectively, further obstruct regional development in peripheral areas. At a local scale, islands of poverty have also developed within the urban centres: Although these centres represent the largest pools of employment in the country, they are simultaneously characterised by highest rates of unemployment and a large informal sector due to the volatility of globalising labour markets. There are no official social security networks in the Philippines to cushion the rural and urban poor in times of crises.

Against this background of a «boom and bust» economy, governmental policies have not managed to create sufficient employment opportunities in the country to compensate the employment-population dilemma. Instead, the state government has pursued an «education for export»-strategy to mitigate (sub-) 
national problems by providing global markets with a Filipino workforce. The Philippines have become the largest global exporter of labour. In the long run, however, the entire country, and particularly so in the peripheries, is being drained of their most productive population and their human capital base - both of which are essential factors for coping with substantial transformations induced by globalisation and for pursuing sustainable endogenous development.

The Filipino people seem to face a problem-ridden future in which they cannot rely on favourable policies by their national and local governments. The responsibility appears to lie within the hands of actors in civil society to fill the gaps.

\section{References}

BürkLIN, W. (2000): Globalisierung als Chance für Wohlstand und Arbeitsplätze. - In: Politik und Zeitgeschichte 48: 31-38.

Commission on Filipinos Overseas (CFO) (2002): Data CD. Personally received in April 2003.

George, T.R. (1998): Local governance. People power in the Provinces? - In: Silliman, S. \& L. Garner Noble (eds.): Organizing for democracy. NGOs, civil society, and the Philippine state. - Honolulu: University of Hawaii Press: 223-253.

Gonzales, E.T., Ramos, C.G., Estrada, G.E.B., AdvinCUlA-Lopez, L.V. \& G.L.A. IgaYA (2003): Managing urbanization under a decentralized governance framework. $-2^{\text {nd }}$ edition, Makati City:Demographic Research and Development Foundation and Philippine Institute for Development Studies.

Hanisch, R. (2000): Die Philippinen in der Asienkrise. - http:/library.fes.de/fulltext/stabsabteilung/00897.htm $12 / 2002$.

Manasan, R.G. \& R.G. Mercado (1999): Regional economic growth and convergence in the Philippines: 1975-1997. - = Philippine Institute for Development Studies Discussion Paper Series No. 99-13.

National Economic and Development Authority (NEDA) (2001): The medium-term Philippine development plan 2001-2004. - Manila.

National Statistical Coordination Board (NSCB) (2001): Countryside in figure. - 2001 edition, Manila.

National Statistical Coordination Board (NSCB) (2002a): Information on provincial administrative classification of the Philippines. - www.nscb.gov.ph 06/2002.

National Statistical Coordination Board (NSCB) (2002b): Philippine statistical yearbook 2002 . Manila.

National Statistical Coordination Board (NSCB) (2003a): List of cities in the Philippines. - www.nscb. gov.ph 05/2003.

National Statistical Coordination Board (NSCB) (2003b): Philippine poverty statistics. - Manila.
Nattonal Statistical Office (NSO) (2001/2002): Census 2000. - www.census.gov.ph 09/2001-12/2002.

Orbeta, A.C. \& E.M. Pernia (1999): Population growth and economic development in the Philippines: What has been the experience and what must be done? - = Philippine Institute for Development Studies Discussion Paper Series No. 99-22.

Pernia, E.M. \& P.F. Quising (2002): Is economic openness good for regional development and poverty reduction? The Philippines. - = Asian Development Bank Economics and Research Department Policy Brief Series No. 10.

Philippine Economic Zone Authority (PEZA) (2003): List of special economic zones by region.- www.peza. gov.ph 02/2003.

RIGG, J. (2003): Southeast Asia. The human landscape of modernization and development. $-2^{\text {nd }}$ edition, London: Routledge.

Schneider, H. (1999): Soziale Strategien der Risikominimierung im informellen Sektor. Das Beispiel des philippinischen Suki-Systems. - In: Geographische Rundschau 51, 12: 662-667.

Shaw, B. (1999): Agriculture in the Philippines. - In: Hooke, G., Warr, P., Shaw, B., Fforde, A. \& C. BRASSARD: Agriculture in times of crisis. Impacts in South East Asia of the economic crisis. - Canberra: Australian Agency for International Development: 43-54.

Science and Technology Education Network (StedNET) (2002): Science and Technology Education Network - http://stednet.sei.dost.gov.ph 12/2002.

Tyner, J.A. (1999): The geography of Philippine international labour fields. - Asia Pacific viewpoint 40, 3 : 217-234.

\section{Summary: Disparate geographies of labour: The Phil- ippines in times of globalisation}

Labour market issues give insight into the myriad ways in which people and politics respond to social and spatial tensions marking current transformations alongside globalisation. This paper explores the relations between the globalising Philippine labour market, spatially disparate development and the course of national economic policies.

Philippine state policies almost exclusively promote global-oriented service and industry sectors and their predominantly urban locations. The agricultural sector, and thus most of the rural regions and inhabitants, is neglected by these policies. Many rural regions find themselves being pushed into the economic periphery. Their inhabitants appear caught in a spiral of increasing poverty, leading to heightened exodus as persons seek employment and better perspectives in urban centres. Persistent inequality of power relations, landownership, socio-political conflicts and slow decentral- 
isation further exacerbate the situation in the peripheries. At the same time, the urban centres struggle to absorb the migrants in the face of economic volatility through globalisation. Unemployment is high and the informal sector large. A strategy of the state government has been to export workforce surplus to global labour markets. In the long run, however, the Philippines, and particularly its peripheries, could loose their most productive human capital, and consequently, their basis for any endogenously driven development. Thus, it appears necessary for the government to provide their citizens with a sustainable, socially and spatially more balanced inner labour market if it wishes to herald in a developmental turnabout.

\section{Zusammenfassung: Disparitäten des Arbeitsmarktes: Die Philippinen in Zeiten der Globalisierung}

Arbeitsmärkte signalisieren die vielfältigen Bewältigungsstrategien von Mensch und Politik gegenüber den sozialen und räumlichen Spannungen einer globalisierenden Wirtschaftswelt. Dieser Aufsatz thematisiert die Zusammenhänge zwischen dem sich globalisierenden philippinischen Arbeitsmarkt, räumlichen Disparitäten und dem politisch-ökonomischen Kurs der philippinischen Regierung.

Die philippinische Regierung fördert fast ausschliesslich den Dienstleistungs- und Industriesektor sowie deren städtische globalisierte Standorte. Der landwirtschaftliche Sektor, der ländliche Raum und ihre Einwohner werden vernachlässigt. Als Folge wandert der produktivste Anteil der Bevölkerung aus den ländlichlandwirtschaftlichen Peripherien kontinuierlich in die urbanen Wirtschaftszentren ab. Die zurückbleibenden Menschen in den Peripherien werden durch politische Konflikte, Naturkatastrophen, ungleiche Macht- und Landverteilung sowie eine stockende Dezentralisierung in immer größere Armut getrieben. Gleichzeitig können die Zentren den Migrantenstrom nicht absorbieren: Arbeitslosigkeit und ökonomische Volatilität der globalisierten Sektoren sind hoch. Die Regierung versucht, diese Engpässe zu überbrücken, indem sie den Überschuss an Arbeitern quasi in den globalen Arbeitsmarkt «exportiert». Auf lange Sicht führt eine solche Strategie jedoch zur Erodierung des Humankapitals und damit des wirtschaftlich-endogenen Fundamentes des Landes und insbesondere der Peripherien. Die philippinische Regierung sieht sich heute mit der Aufgabe konfrontiert, einen räumlich und sozial ausgeglichenen philippinischen Arbeitsmarkt aufzubauen.

\section{Résumé: Les disparités du marché du travail des Philippines à l'heure de la mondialisation}

Les questions relatives au marché du travail renseignent sur la manière dont les populations et les politiques répondent aux tensions sociales et spatiales qui relèvent du contexte actuel de mondialisation. Cet article traite des relations entre le marché du travail en cours de mondialisation des Philippines d'une part, et les disparités spatiales du développement ainsi que l'état d'avancement des politiques (économiques) des Etats d'autre part.

Les politiques de développement mise en place par l'Etat philippin font habituellement la promotion des services mondialisés, de l'industrie et de leurs localisations généralement urbaines. Le secteur agricole et les régions rurales sont négligées par ces politiques; elles deviennent alors des périphéries économiques. Les habitants de ces régions sont atteints par une forte pauvreté et cherchent des emplois dans les centres urbains. Des relations de pouvoir inégales, des conflits socio-politiques et une décentralisation lente exacerbent encore la situation des périphéries. D'une manière simultanée, les centres urbains connaissent des problèmes pour absorber les migrants, dues à la volatilité de l'économie mondialisée. Le chômage y est élevé de même que l'activité informelle. Les politiques de développement gouvernementales répondent à cette situation en employant le surplus de main d'œuvre à des activités destinées aux marchés globaux. A long terme, cependant, les Philippines - et particulièrement ses périphéries - tendent à perdre leur capital humain le plus productif, qui constitue pourtant les bases d'un développement endogène. Le gouvernement philippin est aujourd'hui confronté à la nécessité de construire un marché de l'emploi intérieur soutenable et plus équilibré du point de vue social et spatial, de manière à fournir à sa population une place dans le monde mondialisé.

Dr. Anne Clausen, Kingston University London, School of Earth Sciences and Geography, Penryhn Road, Kingston upon Thames, Surrey, KT1 2 EE, United Kingdom.

e-mail: A.Clausen@kingston.ac.uk

\section{Manuskripteingang/received/manuscrit entré le 7.6.2006}

Annahme zum Druck/accepted for publication/accepté pour l'impression: 14.5.2007 